\title{
Integrating potential fields with remote sensing data for geological investigations in the Eljufra area of Libya
}

\author{
Nureddin Mohamed Saadi ${ }^{1}$, Koichiro Watanabe ${ }^{1}$, Akira Imai $^{1}$, and Hakim Saibi ${ }^{2}$ \\ ${ }^{1}$ Department of Earth Resources Engineering, Kyushu University, 744 Motooka, Fukuoka 819-0395, Japan \\ ${ }^{2}$ Laboratory of Geothermics, Faculty of Engineering, Kyushu University, 744 Motooka, Nishi-ku, Fukuoka 819-0395, Japan
}

(Received May 24, 2007; Revised January 19, 2008; Accepted January 22, 2008; Online published July 4, 2008)

\begin{abstract}
In this study, we successfully integrated geological data, potential field data, and remote sensing data with the aim of investigating and improving our knowledge of the structural setting of the Eljufra area, northwestern Libya. SPOT-5 panchromatic band and digital elevation models (DEM) were used to construct surface shaded maps, and gravity and aeromagnetic surveys were used to provide information on subsurface structures and the nature of intrusive bodies. The results revealed that the prevailing trend of lineaments is NNW-SSE and NNESSW. A Bouguer anomaly map revealed that horst and graben blocks occur inside the large graben. An analytic signal method was applied to the aeromagnetic data to estimate locations and the minimum depths to the contact. A comparison of gravity and magnetic data provided information on hydrothermally altered basalt and sediment density. An anticlinal structure was detected in the western part of the study area. The effects of faults on basalt rocks indicated geological time for volcanic activity.
\end{abstract}

Key words: Libya, Eljufra area, remote sensing, shaded maps, gravity, aeromagnetic, analytical signal.

\section{Introduction}

Interest in studying geological structure by the integration of potential field methods with remote sensing data has grown very rapidly in recent years. In particular, the identification of geological lineaments is considered to be a valuable tool for recognizing geological structure and indicating deformation mechanics (Cortes et al., 1998; de Castro et al., 2002; Morelli and Piana, 2006).

A SPOT-5 panchromatic band $(2.5 \mathrm{~m})$ and digital elevation models (DEM) $(90 \mathrm{~m})$ were used in this study to create surface shaded maps by varying the azimuth and elevation of a simulated sun illumination on a topographic surface. This approach was adopted to emphasize the trends perpendicular and parallel to the sun azimuth, which, in turn, would improve the ability to identify and map geological lineaments. A series of image processing techniques were applied with the overall aim of extracting and mapping lineaments from three-dimensional (3D) images. Contrast stretching was used for accentuating subtle differences in data values in order to enhance spatial detail and improve visual interpretation. Edge enhancement filters were applied to explore pixel distribution of varying brightness over the image and sharpen boundary discontinuities. A Bouguer anomaly map and magnetic intensity map provided quantitative estimates of the basement structural trend, nature of intrusive bodies, horst and graben blocks, and anticlinal structures. The aeromagnetic data were used to create an analytic signal map. The potential field dataset was obtained from the Petroleum Research Centre (PRC), Tripoli,

Copyright (c) The Society of Geomagnetism and Earth, Planetary and Space Sciences (SGEPSS); The Seismological Society of Japan; The Volcanological Society of Japan; The Geodetic Society of Japan; The Japanese Society for Planetary Sciences; TERRAPUB.
Libya.

The aim of this study was to utilize integrated potential fields and remote sensing data to investigate the structural setting of Eljufra area, northwestern Libya. The final results revealed new information on dominant trends of the lineaments, nature of the intrusive igneous bodies, anticline structural features, horst and graben blocks, and geological time for volcanic activity.

\section{Study Area}

Eljufra is an arid area located in the northwestern part of Libya, bounded by longitudes $15^{\circ} 00^{\prime} \mathrm{E}$ to $16^{\circ} 30^{\prime} \mathrm{E}$ and latitudes $29^{\circ} 00^{\prime} \mathrm{N}$ to $29^{\circ} 35^{\prime} \mathrm{N}$. It covers a surface area of approximately $9,000 \mathrm{~km}^{2}$ and appears to be mostly devoid of any vegetation (Fig. 1).

\section{Geological Setting}

The Eljufra area belongs geologically to the eastern part of the Al Hamada al Hamra basin and the western part of the Sirt basin. The Hun Graben (length: 120 km, width: 40$50 \mathrm{~km}$ ) has been considered to be the borderline between the two main regional structural units (Klitzsch, 1970) and appears as a huge furrow cutting through the present-day relief (Tawadros, 2001). The western part of Eljufra area consists of flat terrain, slightly undulating but gently dipping to the northeast. The sediments in this zone are from the Paleocene and Upper Cretaceous except in the southern part, where basalt flows from Jabal Assawda can be found. The eastern area is hilly terrain terminating at the western margin in steep scarp, while a regional dip NENNE is observed. Undulations and gentle domelike structures are noticed in the eastern region belonging to the Sirt basin area. In addition, a few small folds can be noticed 


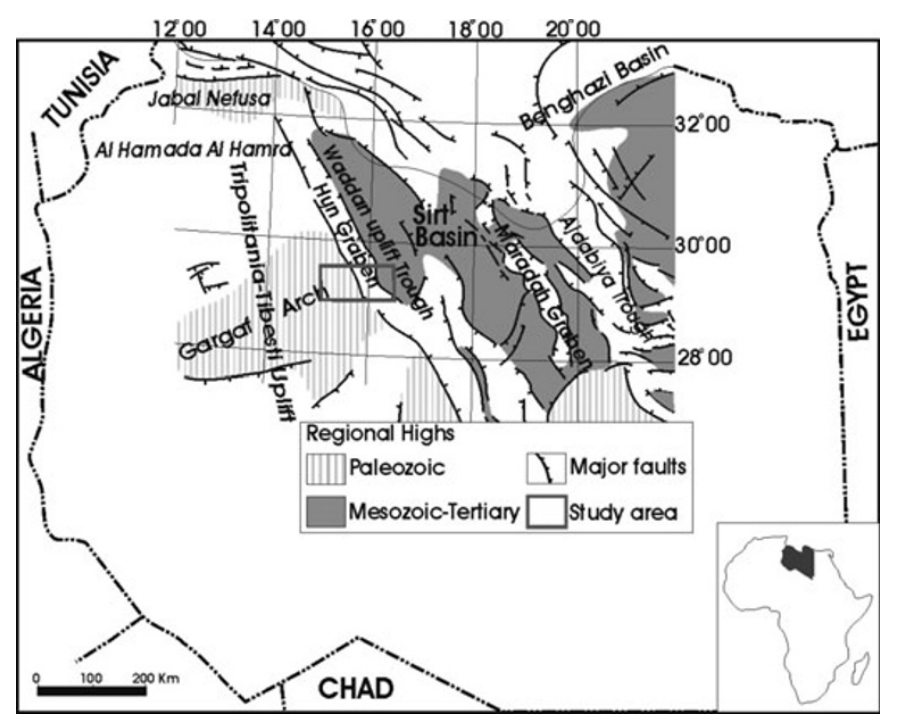

Fig. 1. The study area overlaid by the tectonic map of Libya, modified from Rusk (2001).

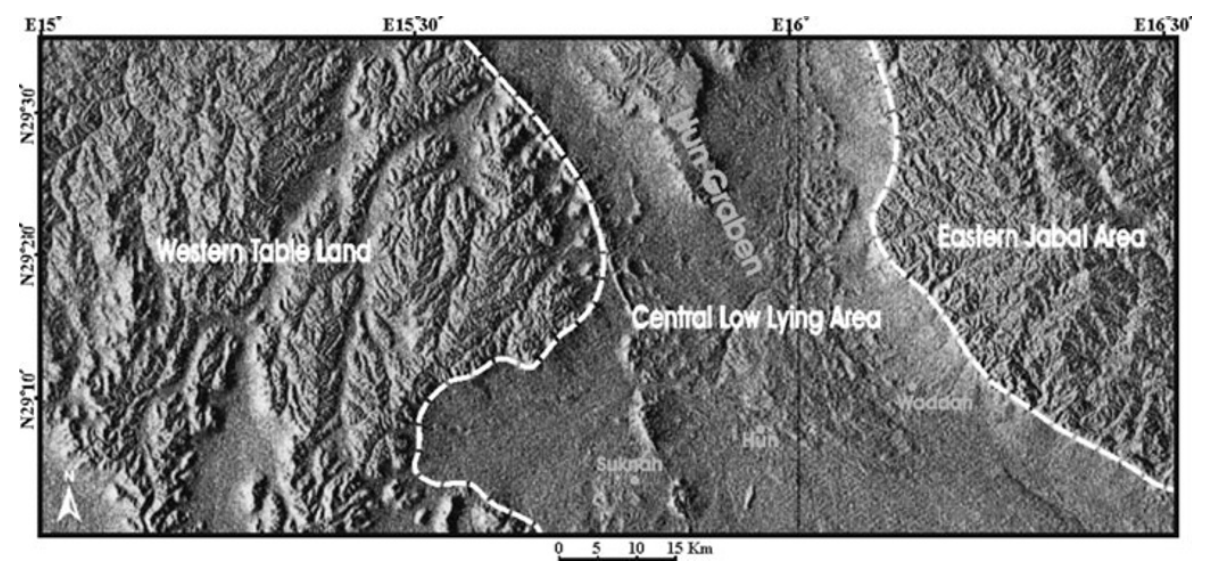

Fig. 2. The topographic map of the study area (Space Shuttle 3-second DEM (NASA, http://www2.jpl.nasa.gov/srtm/)).

within the graben boundary faults (Fig. 2). The direction of the faults adjacent to the graben area is usually in the basic structural direction of NNW-SSE to NW-SE. The dominant trends of the faults show that the graben-forming forces have probably acted with a slight variation of orientation on both edges and reflect the regional structure of the Gargaf uplift in the southern part (Shakoor and Shagroni, 1984). The west boundary of the Hun Graben featured in the fault zone consists of several subparallel faults accompanied by brecciated zones. The nature and origin of the Hun Graben is controversial. Klitzsch (1970) suggested that the tectonic development of the Hun Graben started prior to the Cretaceous and that the western boundary of the graben is Paleocene in age. However, Cepek (1979) inferred that the graben is probably Oligocene in age. The Hun Graben is floored with basement schist and contains sediments ranging in age from Triassic to Oligocene (Anketell, 1996; Hallett and El-Ghoul, 1996). According to Shakoor and Shagroni (1984) the sedimentary rock units of the Hun area range in age from Upper Cretaceous to Tertiary. However, the study area is covered by rocks ranging in age from the Upper Cretaceous to the Quaternary. Volcanic rocks represented by basalt subvolcanic intrusion and extrusive basalt flow cover the southwestern part of the study area.

The Zimam formation (Upper Cretaceous-Paleocene) represents the last sedimentary cycle of the Hamada Group (Jordi and Lonfat, 1963). It was subdivided by Energoprojekt (1975) into the Lower Tar Marl Unit, Socna Unit, Upper Tar Maral Unit, and Had Limestone Unit. The Shurfah Formation (Paleocene), a term first introduced by Jordi and Lonfat (1963) and which was used to encompass the Bu Ras Marlstone, Gelta Chalk, and Operculina Limestone Members, is partly observed in the western part of the study area. The Bishimah Formation (Paleocene-Eocene) was categorized into the Khayir, Wadi Zakim, and Rawaghah Members by Barr and Weegar (1972) and Woller (1978).

Goudarzi (1970) separated the Gir Gypsum from the Bishimah Formation and then divided the latter into the Khayir Marl, Flosculina Limestone, and Rawaghah Members. Woller (1978) described the three members of the Bishimah Formation defined by Goudarzi (1970) and substituted the name Wadi Zakim Member for Flosculina (Alveolina) Limestone (Tawadros, 2001). Lithologically, the Wadi Zakim Member consists of dolomitic chalky limestone and dolomitic sandy marl with gypsum. The Al Jir Formation (Eocene) was introduced by Burollet (1960). It 


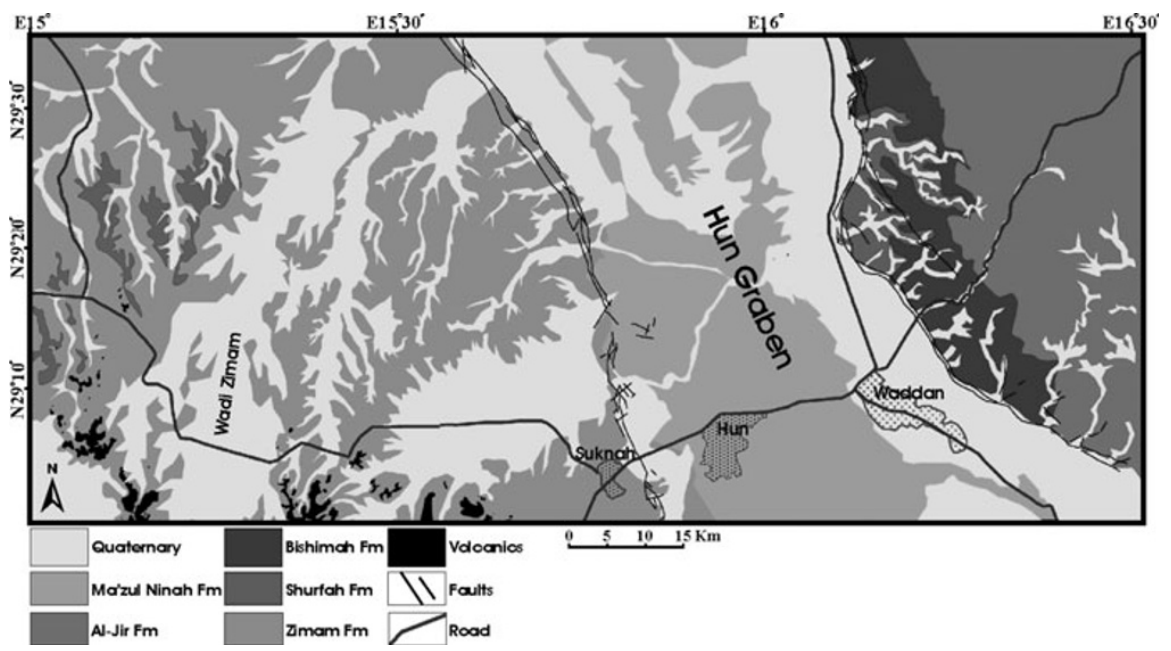

Fig. 3. The geological map of Eljufra area.

is treated as an independent unit covering the sequence of sediments overlying the Bishima Formation and underlying Wadi Thamat Formation. The sediments of the Al Jir Formation are well exposed in the east of the study area, encompassing a major area stretching from north to south. It is composed of silicified limestone, calcilutite-dolomitic, and chalky and occasional coquinoidal limestone. The Wadi Thamat Formation (Eocene) was subdivided into Al Gata and Thamat al Qasur Members by Shakoor and Shagroni (1984). Goudarzi (1970) raised the Wadi Thamet Formation to group status and designated the three members as formations. Lithologically, it consists of chalky marl, calcilutite, calcarenite, and coquinoidal marly limestone. The Mazul Ninah Formation (Oligocene) is the youngest and most preQuaternary sediment filling the Hun Graben. The deposits of Ma'zul Ninah (Lower and Upper Members) are composed mostly of siliceous calcilutite, marly nodular limestone, calcareous clay, gypsum, and dolomitic limestone. The Mazul Ninah Formation in the Hun Graben is assumed to uncomformably overlie the Ypresian Rawaghah Member of the Bishima Formation and is overlain by the Miocene volcanics of the Jabal Assawda (Tawadros, 2001). The Tertiary volcanic is dispersed in the south, but in a relatively small area, and it represents the northerly continuation of the main lava massif of the Jabal Asswda. Effusions are present in the form of either fissure eruption lava-flood basalts or central eruption lavas of volcanic cones. The subvolcanic intrusive type is mainly in the form of plugs. The individual flows do not show any presence of pyroclastic or sedimentary interlayer. The subvolcanic intrusives are more pronounced within the graben itself, nearer to the western escarp. They intrude mostly into the older sedimentary rocks belonging to the Zimam Formation and into the graben area to the Ma'zul Formation (Shakoor and Shagroni, 1984). The period of Jabal Assawda volcanism was considered to be post-Oligocene by Klitzsch (1970), Miocene to Pliocene by Schult and Soffel (1973), and Late Oligocene to Middle Miocene by Jurak (1978). The lava flows comprise alkali olivine basalts, with variations from olivine basalt to nepheline basanites (Woller and Fediuk, 1980). All types of Quaternary sediments in the study area unconformably overlie the pre-Quaternary units. The Quaternary sediments in the study area were classified according to their morphological position, genetic criteria, and probable chronological succession into eight types: fluvio terraces, landslides and rock slumps, proluvial deposits, alluvial fans, sabkha sediments, fluvio-eolian deposits, wadi deposits, and eolian deposits (Fig. 3).

\section{Remote Sensing Data}

Two types of criteria were used for lineament extraction: geomorphological criteria based on diagnostic expression of morphotectonics and spectral criteria based on differences in tone, contrast, among others (Morelli and Piana, 2006). Contrast stretching and edge enhancement filters were applied to the SPOT-5 panchromatic band in order to improve visual interpretation and emphasize highfrequency details so as to enhance or sharpen linear features in the image. The intent of contrast stretching is to expand the narrow range of brightness values typically present in an input image over a wider range of grey values. The result is an output image designed to accentuate the contrast between features of interest to the image analyst (Lillesand and Kiefer, 2000). Histogram equalization improves the results of linear contrast stretching as the latter improves the contrast of most original image brightness values; however, there is always a loss of contrast at the extreme high and low end of digital number values (Sabins, 1987). Edge enhancement is performed first, detecting edges and then either adding these back into the original image to increase contrast in the vicinity of an edge, or highlighting edges using saturated (black, white, or color) overlays on borders (Richards, 1993). An edge represents discontinuities or sharp changes in the grey scale value of a particular pixel at a point, and it may be interpreted in terms of geological structure or relief (Mather, 1993). Generally, two types of filters were used in our study. Nondirectional filters were used to enhance linear features in all orientations in an image, with the exception of linear features oriented parallel to the direction of filter movement, which are not enhanced. The other filters were directional filters, which were used to enhance specific linear trends in an image. An NW $3 \times 3$ 


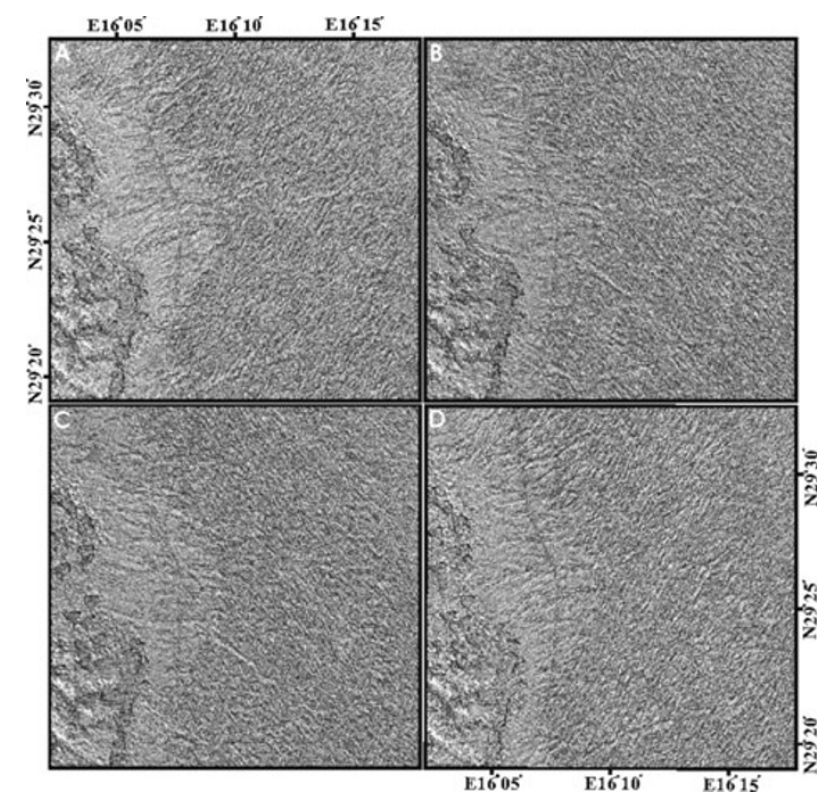

Fig. 4. Partial frame of shaded maps shows sun illumination simulation from four directions. (a) Azimuth NW, elevation $30^{\circ}$. (b) Azimuth NE, elevation $34^{\circ}$. (c) Azimuth SW, elevation $35^{\circ}$. (d) Azimuth SE, elevation $39^{\circ}$.

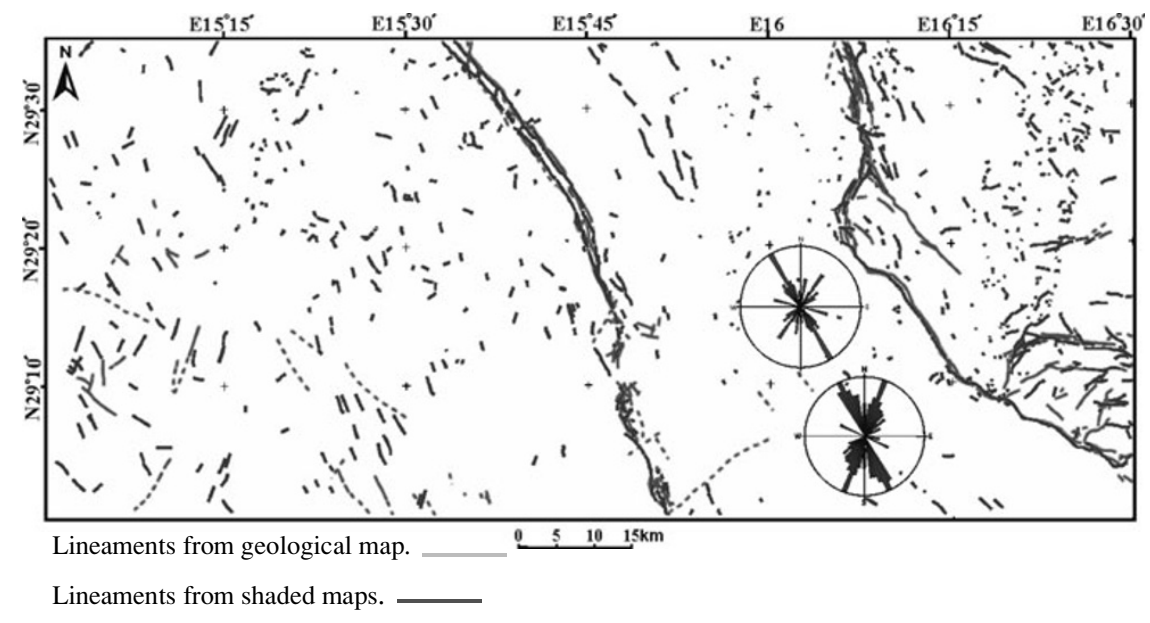

Fig. 5. Lineaments and rose diagrams extracted from geological map and shaded maps of Eljufra area.

edge detection filter was applied according to the lineament trends of the study area (Industrial Research Centre, 1984), and a Laplacian filter was applied to enhance linear features in all other directions. A high pass $1 \times 33$ (central minus filter window mean) was used to enhance high-frequency details of images for detecting and mapping edges.

The orthorectified SPOT 5 panchromatic band draped over DEM elevation data was used to create surface shaded maps by changing the azimuth and elevation of simulated sun illumination for emphasizing trends perpendicular and parallel to the sun azimuth. The initial evaluating of shaded surface maps enabled lineament identification and mapping. Results from previous studies indicated that the dominant trend of the study area is NNW-SSE to NW-SE (Industrial Research Centre, 1984). Therefore, sun illumination coming from NE-ENE was used to avoid azimuth biasing effects (Jansson and Glasser, 2005) and to enhance the visual detection of linear features in the dominant trend. Multiazimuth and elevation angles of simulated sun illumination on the topographic surface were tested to improve the possibility of lineament identification (Fig. 4). In addition to the NE-ENE azimuth angle, the NW-WNW angle was very useful for detecting and mapping lineaments in the study area, especially in the trend of NNE-SSW. Directions of NE-ENE and NW-WNW have been widely used for creating shaded maps and extracting geological lineaments in multi trends and angles. The low elevation of sun illumination $\left(30^{\circ}-40^{\circ}\right)$ was more significant for lineament detection in both directions. Moreover, the zoom facility introduced more flexibility for visual interpretations and correlation determinations between many linear features in the area of study.

The shaded maps extracted about 384 lineaments distributed over the area (253 in the NE-ENE azimuth angle and 131 in the NW-WNW azimuth angle), while 89 lineaments were extracted from the geological map. New lineaments were detected in the central part of the graben, toward the north part of the study area as well as in the eastern 


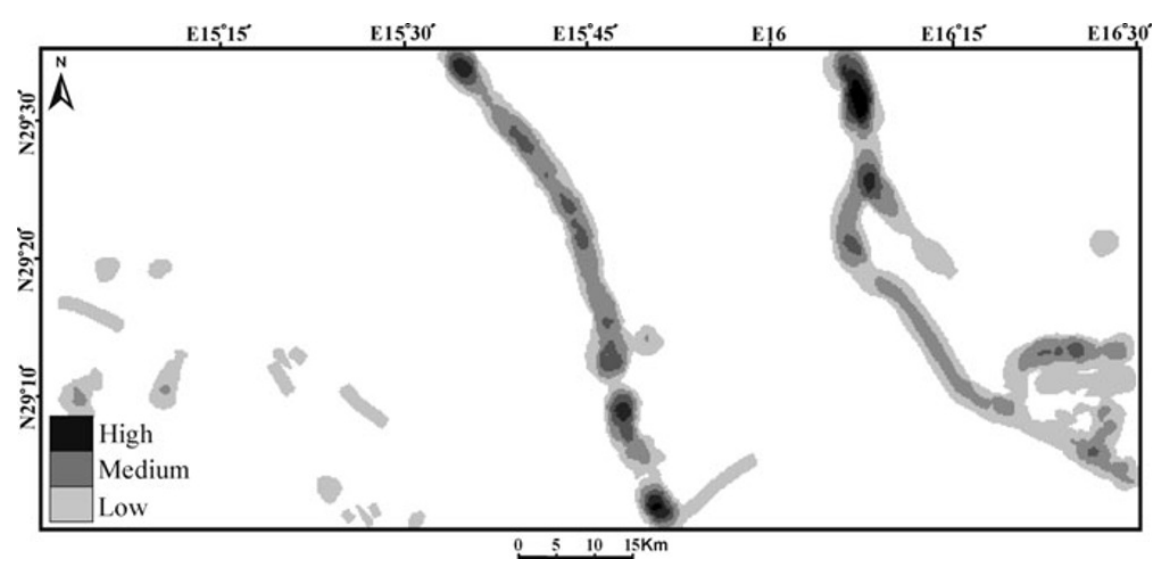

Fig. 6. Density map of lineaments extracted from the geological map.

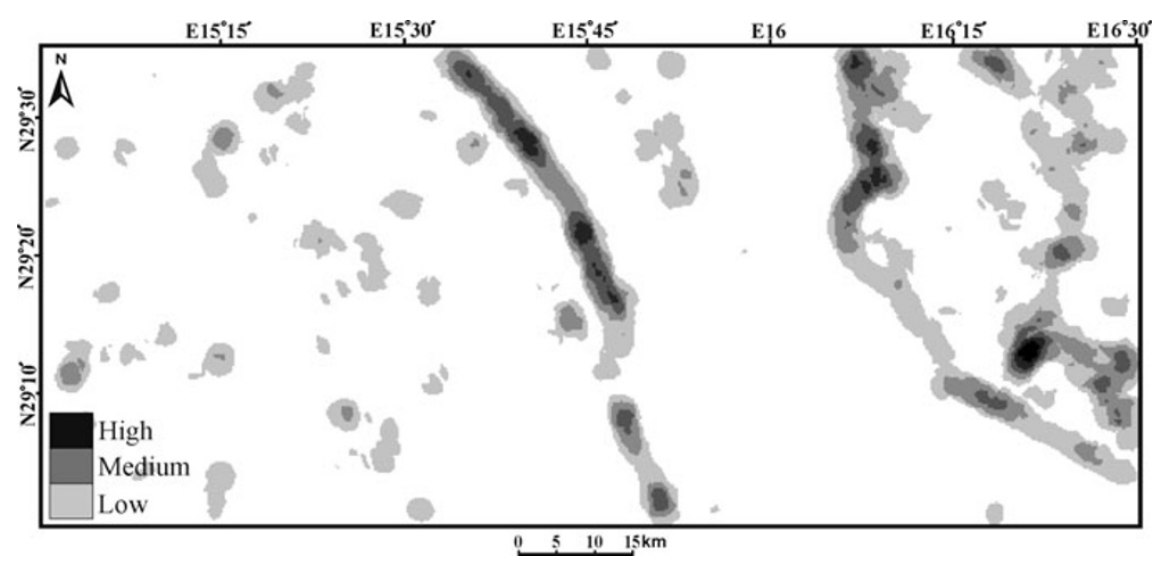

Fig. 7. Density map of lineaments extracted from the shaded maps.

and western regions, which did not appear in the geological map. The eastern region exhibited long lineaments trending NNW-SSE but, in general, lineaments of shaded maps were shorter than lineaments extracted from the geological map. The maximum linear length detected was $3612 \mathrm{~m}$, while the minimum length was $147 \mathrm{~m}$ (Fig. 5).

Density maps of lineaments constructed from remote sensing data and geological map data exhibited an increase in the edges of the Hun Graben and a distinct decrease in other regions. A satellite image showed secondary maxima in the southeastern part of the study area (Figs. 6, 7). Conversely, there are few lineaments in the southern part of the graben, as also observed in the previous field study. The lineaments generally indicate a close relationship with the Hun Graben faults, which are considered to be the dominant tectonic structure of the study area. The rose diagrams obtained from remote sensing data and the geological map showed disagreement in the superior direction, whereas the dominant trend of the geological map is NNW-SSE to NW$\mathrm{SE}$ and the dominant trend of remote sensed lineaments is NNW-SSE and NNE-SSW.

\section{Gravity Survey}

The gravity data was obtained from the Petroleum Research Centre (PRC), Tripoli, Libya, from a total of 120 gravity stations at a station spacing of 700-7000 $\mathrm{m}$ and over an area of approximately $9000 \mathrm{~km}^{2}$. For gridding the data, we converted the geodetic coordinates to $x-y$ coordinates using projection NUTM34 and Datum WGS84. The gravity survey stations are not line-based, and the observation intervals are not equally spaced. Therefore, the data were transformed to the grid, based on the minimum curvature surface method, with a grid cell size of $1 \mathrm{~km}$, to create the Bouguer anomaly map (Fig. 8). It should be noted that gravity stations did not cover the entire area, but mainly the southern and part of the northern areas. Gravity data were corrected for temporal variations (drift and tides). Free air and terrain corrections were applied to the observed gravity. A density of $2.67 \mathrm{~g} / \mathrm{cm}^{3}$ was used to yield the Bouguer anomaly map of the study area, as shown in Fig. 8. Variations in gravity anomalies are normally caused by variations in the density of subsurface rocks (Reynolds, 1997), and they usually indicate faults or lithological contacts. Figure 8 shows that the entire area is characterized by negative Bouguer anomalies, ranging from -47.4 to $-17.9 \mathrm{mGal}$, indicating that the continental rocks have a low density and thickness. The Hun Graben is characterized by irregular high-gravity anomalies that suggest the deposition of relatively dense sedimentary rocks. Variations of high and low Bouguer anomalies observed inside the graben indicate horst and graben blocks, respectively. The highest anomalies noticed in the south can be interpreted to be intrusive bodies into the sedimentary rocks. Gravity anomalies were compared with known geological features of the study area to estimate the relationship 


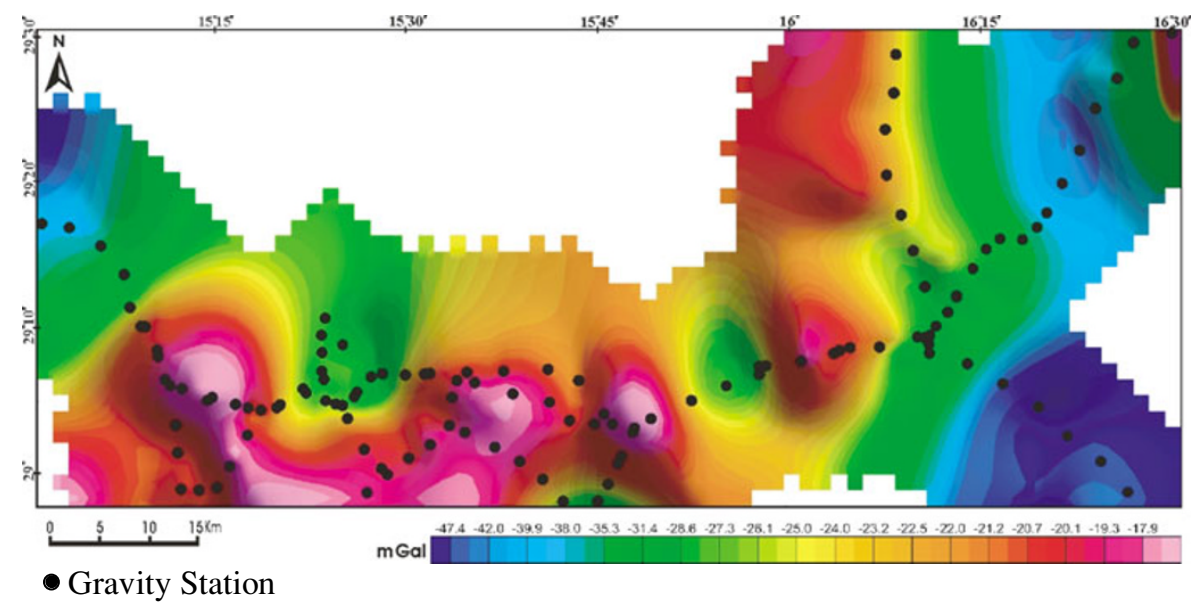

Fig. 8. Stations and Bouguer anomaly map of the study area.

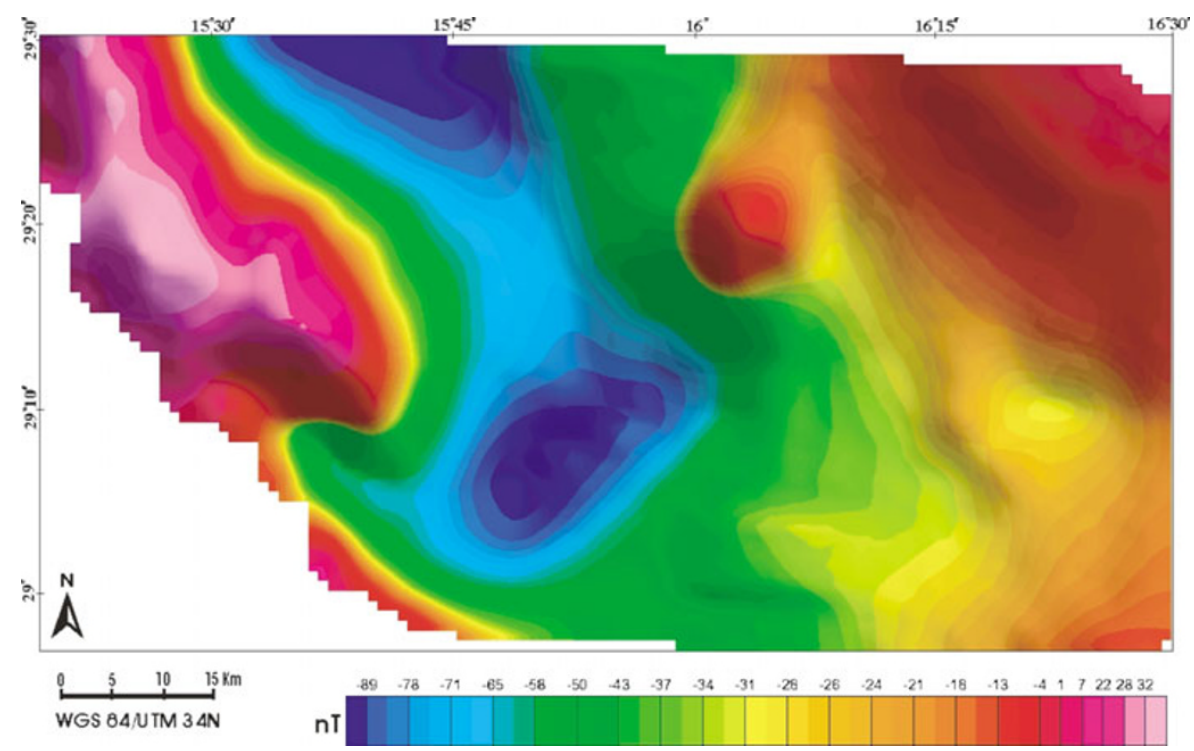

Fig. 9. Magnetic intensity map of the study area.

between total field expressions and the known geology.

\section{Aeromagnetic Survey}

The aeromagnetic data were also provided by the PRC as grid data, a with grid cell size of $1000 \mathrm{~m}$. This survey was carried out along a set of parallel flight lines at 2-km spacing, while the flight height was $755 \mathrm{~m}$ a.s.1. The aeromagnetic data were corrected and reduced to their final form. The magnetic intensity map was constructed with the aim of enhancing geological structures and for qualitative interpretation (Fig. 9). Aeromagnetic anomalies can be used to extract important information about the locations of buried faults, magnetic bearing rocks, and the thickness of the sedimentary rocks within sedimentary basins. The majority of the area is characterized by negative magnetic anomalies. The Hun Graben was clearly represented as a minimum magnetic closure $(-89$ to $-34 \mathrm{nT})$ surrounded by higher magnetic anomalies, and the dominant trend within the graben is NW-SE. The minimum values occurring in the center of the graben $(-89$ to $-71 \mathrm{nT})$ indicate graben blocks and prove that the basement is involved in the struc- ture. The high positive magnetic anomalies reflected in the western part (1-32 nT) indicate the presence of highly magnetic material. This can be interpreted as an anticline structure defining the existence of outcrops of Upper Cretaceous rocks (the oldest unit in the area) on the surface. The magnetic data did not show intrusive igneous bodies, contrary to the gravity data.

\section{Analytic Signal Method}

The basic concepts of the analytic signal method using 2D magnetic data were extensively discussed by Nabighian (1972, 1974, 1984) and Green and Stanley (1975). Roest et al. (1992) showed that the amplitude (absolute value) of the $3 \mathrm{D}$ analytic signal at location $(x, y)$ can be easily derived from the three orthogonal gradients of the total magnetic field. In the analytic signal method, it is assumed that the causative sources are magnetic contacts. The depth was estimated using the width of the analytic signal anomalies between inflection points (MacLeod et al., 1993). The analytic signal signature of the Eljufra area was calculated (Fig. 10) in the frequency domain using the fast Fourier 


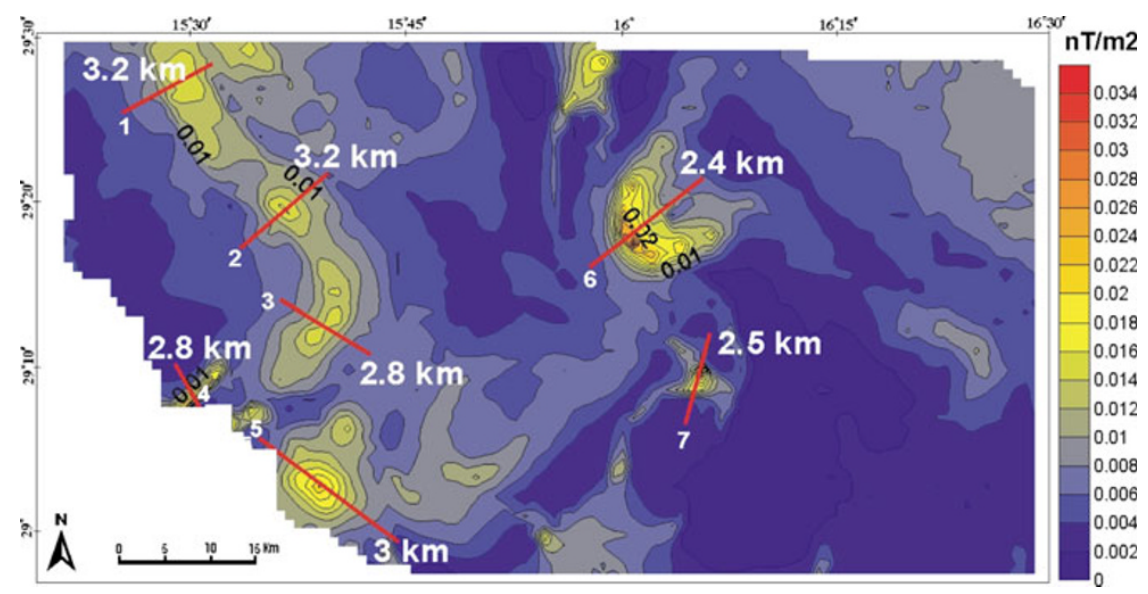

Fig. 10. Analytic signal of magnetic data of Eljufra area. Lines 1-7 are the selected profiles that were used to estimate the depths from the analytic signal.

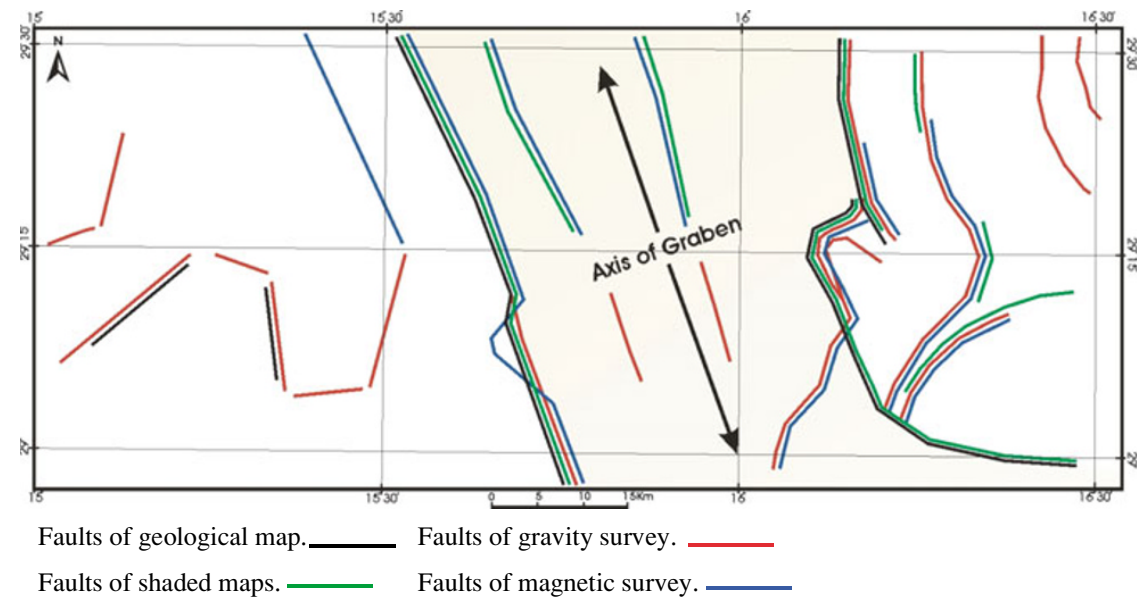

Fig. 11. Correlation and relation between all estimated faults.

transform technique (Blakely, 1995). Higher values of the analytic signal are observed mainly in some regions of the study area (Fig. 10), indicating that these regions have significant density contrasts that produce identifiable signatures on the map. To estimate the depth of the contacts from the analytic signal, we selected seven profiles over the regions where contrasts could be found. The depth values for these regions generally average $2.5 \mathrm{~km}$.

The estimated faults (Fig. 11) comprise the integration of all faults detected by field work, remote sensing data, and the gravity and magnetic surveys. The geological map (Fig. 3) clearly shows that the faults successfully traverse many lithological units and clearly represent the boundaries between rock units.

\section{Discussion and Conclusions}

All lineaments detected in the study area, as determined from remote sensing data, potential fields, and geological study, have affected all of the sedimentary rocks with steep and high angles, and most of these faults show a notable amount of gravity changing. The dominant trends of the faults on the edges of the Hun Graben are mostly in agreement with the structural direction NNW-SSE to NW-SE, which indicates that the force of the Hun Graben formation probably acted - with slight variations in orientation-on both edges. In the eastern and southern regions, the dominant trends of faults are intercepted by faults trending NESW to ENE-WSW in addition to branching off of the faults, which can indicate typical development of graben bounding faults. Most of the small lineaments in younger sedimentary rocks, which may represent joints and fractures, are parallel to the dominant trend of the Hun Graben. The density maps of the lineaments show different patterns, mainly because satellite imagery detected a larger variety of lineaments. Two maxima are distributed over the entire study area, and these are recognizable in both maps (Figs. 6, 7). The dominant trend in the higher density regions is mainly NNW-SSE to NW-SE, while in the low-density regions the individual lineaments with random directions appear in the rose diagrams (Fig. 5). The new trend (NNE-SSW) appears in the rose diagram of remote sensing imagery (Fig. 5). The subparallel faults appearing along the edges of graben indicate the existence of horst and graben blocks inside the graben itself. The results obtained from the gravity investigation indicate the occurrence of tectonic movement inside the Hun Graben. Low-gravity anomaly expressions are normally associated with low structural features (troughs), while highgravity anomaly expressions are associated with high struc- 
tural features (platforms). However, the geological features within the Hun Graben are characterized by reverse gravity expressions, which could be the result of the deposition of relatively dense sedimentary rocks filling the graben. The appearance of high- and low-gravity anomalies inside the graben suggests that the graben itself is constituted of parallel faults, thereby creating horst and graben blocks. Intrusions of basalt and basalt flow were noticeable in the southwestern part of the area and along the western edge of the graben. They affected mostly older Cretaceous-Paleocene sedimentary rocks in the west part of the graben, while in the graben area itself, they affected younger Oligocene sedimentary rocks. The Bouguer anomaly map showed clearly intrusive bodies inside and outside the Hun Graben from the west, which means that the southwestern part of the Eljufra area was a weakened region at the time of volcanic activity.

A high magnetic anomaly observed in the western part of the study area indicates a dome or anticline structure, probably caused by an intrusive igneous body or basement uplift. This could correspond to the existence of Upper Cretaceous rock outcrops (the oldest formation) on the surface of the western region. Low magnetic anomalies inside the graben indicate that a number of faults created graben blocks. Surprisingly, the magnetic intensity map does not show basalt intrusion, and extrusive basalt flow covers the southwestern part of the study area, while the gravity map shows a high anomaly zone along intrusive and extrusive basaltic bodies. There are two lines of thought explaining this result. One is that the basaltic rocks are hydrothermally altered; hence, they are not a magnetic body but a high-density body. The second is that the rock is weakly or reversely magnetized; consequently, a relatively deep intrusion can be detected on the gravity map but not on the magnetic map. According to Shakoor and Shagroni (1984), calcite represents a frequent secondary mineral in the effusive basalt. In addition, the chemical composition of six samples of basalt flows from the study area showed a high rate of L.O.I (14.06, 13.40, $13.80,12.63,14.00$, and 12.84). One possible explanation is that the intrusive basalt is basically identical to that of the effusive, which makes the idea of hydrothermally altered basalt more reasonable. The analytic signal method of magnetic data showed an average minimum depth to the contact of $2.5 \mathrm{~km}$. More analytically, the west edge of the graben $(2.8-3.2 \mathrm{~km})$ is deeper than the east edge $(2.4-2.5 \mathrm{~km})$. This indicates that the western area is weakened in comparison with the eastern area.

Based on the results of remote sensing and gravity data, the volcanic rocks in the south are not affected by the tectonics of the Hun Graben marginal faults. The last movements of these faults are recognized to have taken place in the Oligocene. In addition, the basaltic flows overlie Oligocene rocks (Ma'zul Ninah Formation) inside the graben itself. Therefore, this result suggests that the period of volcanic activity started in the post-Oligocene and possibly extended into the Quaternary.

The estimated faults map exhibited a good agreement between faults extracted from remote sensing data, the geological study, and the field potential methods. Almost all estimated faults show one dominant trend (NW-SE) that represents the edges of Hun Graben. Some faults clearly tra- verse lithological units and reflect the boundaries of formations, such as Bishimah Formation. Conversely, the results show disagreement in the detection and reflection of the eastern edge of the graben. Geological and remote sensing data show this edge to be inclined in a southeast direction, while gravity and magnetic survey show this edge inclined to the south. This type of discrepancy may be a reflection of noise related to cities or the limitations of ground stations. Otherwise, the possibility of the existence of a steep regional trend lowering to the south is dissimilar to the prevailing trend of the Hun Graben. Further studies are necessary to understand the effects of tectonic movement on the rock units and to review the geological history by analyzing and determining sediments and depth of the Hun Graben.

Acknowledgments. We would like to thank Dr. Lucas Donny Setijadji for suggesting a number of improvements to this manuscript. We also thank Dr. Hirofumi Muraoka and an anonymous reviewer for revision and their useful comments which improved the paper. Dr. Akira Takada is thanked for editorial efforts. Dr. Hakim Saibi recognizes the Japanese Society for the Promotion of Science (JSPS) for supporting him in this research.

\section{References}

Anketell, J. M., Structural history of the Sirt basin and its relationship to the Sabrata basin and Cyrenaica platform, northern Libya, in The Geology of the Sirt basin, Vol. III, edited by M. J. Salem, M. T. Busrewil, A. A. Misallati, and M. A. Sola, pp. 57-89, Elsevier, Amsterdam, 1996.

Barr, F. T. and A. A. Wegar, Stratigraphic Nomenclature of the Sirt Basin, Libya, Petrol. Explor. Soc. Libya, 199 p., Tripoli, 1972.

Blakely, R. J., Potential Theory in Gravity and Magnetic Applications, Cambridge University Press, 1995.

Burollet, P. F., Lexique Stratigraphique International, Afrique, Fasc. IVa, Libya, Names and Nomenclature Committee Geol. Cong 20th Intern. Geol. Cong., Mexico, 1960, Centre Nat. de la Recherche Sci., 62 p., Paris, 1960.

Cepek, P., Geological map of Libya, 1:250,000, Sheet Al Qaryat Ash Sharqiyah, Industrial Research Centre, Tripoli, Libya, 1979.

Cortes, A., A. Maestro, M. Soriano, and A. Casas, Lineaments and fracturing in the Neogene rocks of the Almazán Basin, northern Spain, Geol. Mag., 135, 255-268, 1998.

de Castro, D., R. Branco, G. Martins, and N. de Castro, Radiometric, magnetic, and gravity study of the Quixadá batholith, central Ceará domain (NE Brazil): evidence for Pan-African/Brasiliano extensioncontrolled emplacement, J. South Am. Earth Sci., 15, 543-551, 2002.

Energoprojekt, Wadi Sawfajjin—Wadi ZamZam—Al Jufrah Regional Hydrogeological study, Final Report, Unpublished Report, General Water Authority, Tripoli, 1975.

Goudarzi, G. H., Geology and mineral resources of Libya. A Reconnaissance, Geol. Survey, U.S., Prof. Paper 660, pp. 104, 1970.

Green, R. and J. M. Stanley, Application of a Hilbert transform method to the interpretation of surface-vehicle magnetic data, Geophys. Prospect., 23, 18-27, 1975.

Hallett, D. and A. El Ghoul, Oil and gas potential of the deep trough areas, in the Sirt Basin, Libya, in The geology of Sirt Basin, edited by M. J. Salem, A. S. El-Hawat, and A. M. Sbeta, v. II, p. 455-484, Elsevier, Amsterdam, 1996.

Industrial Research Centre (I.R.C.), Geological map of Libya, 1:250,000, sheet: Hun, Tripoli-Libya, 1984.

Jansson, K. and N. Glasser, Using Landsat 7 ETM+ imagery and digital terrain models for mapping glacial lineaments on former ice sheet beds, Int. J. Remote Sens., 26, 3931-3941, 2005.

Jordi, H. A. and F. Lonfat, Stratigraphic subdivision and problems in Upper Cretaceous-Lower Tertiary Deposits in Northwestern Libya, Rev. Inst. Fran. Petrole, 18, 1428-1436, 1963.

Jurak, L., Geological map of Libya, 1:250,000, Explanatory booklet, sheet Nabal Al Hasawnah, NH 33-14, Industrial Research Center, Tripoli, 1978

Klitzsch, E., Die strukturgeschichte der Zentralsahara, Geol. Rdsch., 59, 459-527, 1970.

Lillesand, T. M. and R. W. Kiefer, Remote sensing and image interpreta- 
tion, fourth edition, John Wiley \& Sons, New York, 2000.

MacLeod, I. N., K. Jones, and T. F. Dai, 3-D analytic signal in the interpretation of total magnetic field data at low magnetic latitudes, Explor. Geophys., 24, 679-688, 1993.

Mather, P. M., Computer processing of remotely sensed images, John wiley \& Sons, Chichester, New York, Brisbane, Toronto, Singapore, 1993.

Morelli, M. and F. Piana, Comparison between remote sensed lineaments and geological structures in intensively cultivated hills (Monferrato and Langhe domains, NW Italy), Int. J. Remote Sens., 27, 4471-4493, 2006.

Nabighian, M. N., The analytic signal of two-dimensional magnetic bodies with polygonal cross-section: its properties and use for automated anomaly interpretation, Geophysics, 37, 507-517, 1972.

Nabighian, M. N., Additional comments on the analytic signal of twodimensional magnetic bodies with polygonal cross-section, Geophysics, 39, 85-92, 1974.

Nabighian, M. N., Toward a three-dimensional automatic interpretation of potential field data via generalized Hilbert transforms: Fundamental relations, Geophysics, 49, 780-786, 1984.

NASA (http://www2.jpl.nasa.gov/srtm/): Shuttle Radar Topography Mission (SRTM-DEM).

Reynolds, J., An introduction to applied and environmental geophysics, John Wiley \& Sons Ltd, England, 1997.

Richards, J. A., Remote sensing digital image analysis, an introduction, second edition, Springer, Berlin, 1993.
Roest, W. R., J. Verhoef, and M. Pilkington, Magnetic interpretation using 3-D analytic signal, Geophysics, 57, 116-125, 1992.

Rusk, D. C., Libya: Petroleum potential of the underexplored basin centers-A twenty-first century challenge, in Petroleum provinces of the twenty-first century: AAPG Mem., edited by M. W. Downey, J. C. Threet, and W. A. Morgan, 74, 429-452, 2001.

Sabins, F. F., Jr., Remote sensing principals and interpretation, 2nd edn., Freeman, New York, 1987.

Shakoor, A. and Y. Shagroni, Geological map of Libya, 1:250,000, Explanatory Booklet, Sheet Hun NH 33-11, Industrial Research Centre, Tripoli, Libya, 1984.

Schult, A. and H. Soffel, Paleomagnetism of Tertiary basalts from Libya, Geophys. J. R. Astron. Soc., 40, 491-499, London, 1973.

Tawadros, E., Geology of Egypt and Libya, 480 pp., A. A. Balkema, Rotterdam, 2001.

Woller, F., Geological Map of Libya 1:250,000, Explanatory Booklet, Sheet Al Washkah NH33-15, Industrial Research Centre, Tripoli, 1978.

Woller, F. and F. Fediuk, Volcanic rocks of Jabal as Sawada, Geol. Libya, 3, 1081-1093, 1980.

N. M. Saadi (e-mail: saadi-n@mine.kyushu-u.ac.jp), K. Watanabe, A. Imai, and H. Saibi 